\title{
Hubungan Panjang - Berat, Faktor Kondisi dan Ukuran Pertama Kali Tertangkap Ikan Tuna Sirip Kuning (Thunnus Albacares) di Pelabuhan Perikanan Samudra Cilacap
}

\author{
Length - Weight Relationship, Condition Factors and Legth of The First Time Caught of Yellowfin Tuna (Thunnus \\ albacares) in Cilacap Ocean Fishing Port
}

Nurul Amin Azizi, Suradi Wijaya Saputra, Abdul Ghofar

Program Studi Manajemen Sumberdaya Perairan, Jurusan Perikanan

Fakultas Perikanan dan Ilmu Kelautan, Universitas Diponegoro

J1. Prof. Soedarto, SH, Tembalang, Semarang, Jawa Tengah - 50275, Telp/Fax. +6224 7474698

Email :nurulazizi097@gmail.com

\begin{abstract}
ABSTRAK
Ikan Tuna Sirip Kuning (Thunnus albacares) yang ditangkap di Samudera Hindia merupakan komoditas penting karena memiliki nilai manfaat dan ekonomis yang tinggi. Berdasarkan hal tersebut, perlu dilakukan penelitian mengenai parameter yang mempengaruhi populasi tuna sirip kuning. Penelitian ini bertujuan untuk mengetahui struktur ukuran, hubungan panjang dan berat, faktor kondisi serta ukuran pertama kali tertangkap. Penelitian ini dilakukan pada bulan Juli-Agustus 2019 di Pelabuhan Perikanan Samudera Cilacap. Jumlah sampel tuna sirip kuning sebanyak 267 ekor dari 27 kapal yang melakukan bongkar di lokasi penelitian. Metode pengambilan sampel adalah dengan mengukur panjang dan berat. Hasil pengukuran yang diperoleh kemudian dilakukan analisis statistik dengan melakukan perhitungan dan hipotesis. Sampel ikan yang digunakan dalam penelitian ini yaitu ikan tuna sirip kuning dengan ukuran >0,5 meter dan berat $>15$ kilogram. Sampel kapal merupakan kapal tuna longline dengan ukuran >10 GT (Gross Tonage). Hasil penelitian didapatkan ukuran panjang antara 88-174 cmFL (panjang cagak) dan berat antara 17-98 kilogram. Hubungan panjang dan berat bersifat allometrik negatif. Faktor kondisi diperoleh sebesar 0,97-1,25. Ukuran pertama kali tertangkap (Lc) sebesar $140 \mathrm{cmFL}$. Lc > Lm, menunjukan ikan tuna sirip kuning yang tertangkap sudah pernah memijah dan diperbolehkan ditangkap.
\end{abstract}

Kata Kunci : Ikan Tuna Sirip Kuning; Panjang-Berat; Faktor Kondisi; Struktur Ukuran; Samudera Hindia

\section{ABSTRACT}

Yellowfin Tuna (Thunnus albacares) caught in the Indian Ocean is an important commodity because it has high economic and benefits. Based on this, research needs to be done on the parameters that affect yellow fin tuna population. This study aims to determine the size structure, length and weight relationship, condition factors and the leght of the first time caught. This research was conducted in July-August 2019 at the Cilacap Ocean Fishing Port. The number of yellowfin tuna samples was 267 from 27 ships unloading at the study site. The sampling method is by measuring length and weight. The measurement results obtained are then carried out statistical analysis by doing calculations and hypotheses. Yellow fin tuna samples>> 0.5 meters in size and 15 kilograms in weight. The sample ship is a longline tuna ship with size> $10 \mathrm{GT}$ (Gross Tonage). The results showed a length of between 88-174 cmFL (fork length) and a weight of 17-98 kilograms. The length and weight relationship is negative allometric. The condition factor is obtained from 0.97 to 1.25. Length of first catch $(L c)$ was $140 \mathrm{cmFL}$. Lc> Lm, indicating that yellowfin tuna caught have spawned and are allowed to be caught.

Keywords: Yellowfin Tuna; Biological Aspects; Length-Weight; Condition Factors; Size Structure; Indian Ocean

\section{PENDAHULUAN}

Pelabuhan Perikanan Samudra (PPS) di Kabupaten Cilacap merupakan salah satu pelabuhan terbesar di bagian selatan Jawa.Sebagai pelabuhan utama di Kabupaten Cilacap, Pelabuhan Perikanan Samudra menjadi tempat pendaratan berbagai macam hasil perikanan terutama hasil tangkapan ikan tuna yang ditangkap di perairan Samudra Hindia.Kabupaten Cilacap memberikan kontribusi produksi perikanan laut bagi Provinsi Jawa Tengah yang paling tinggi dibandingkan dengan kabupaten/kota lainnya. Menurut Komisi Nasional Pengkajian Stok Sumberdaya Ikan Laut, potensi sumberdaya ikan di Samudera Hindia selatan jawa termasuk Pelabuhan Perikanan Samudera Cilacap cukup besar yaitu 80.000 ton/tahun (Adhitya et al., 2012).

Wilayah perairan Kabupaten Cilacap merupakan wilayah Samudra Hindia Selatan Jawa, merupakan Wilayah Pengelolaan Perikanan (WPP) 573.Hasil tangkapan ikan di Pelabuhan Perikanan Cilacap mengalami kenaikan setiap tahunnya. Menurut hasil laporan tahunan PPS Cilacap tahun 2017, produksi ikan yang didaratkan pada tahun 2017

\footnotetext{
${ }^{\circ}$ Copyright by Management of Aquatic Resources (MAQUARES)
} 
sebesar $11.834,12$ ton atau menengalami kenaikan (48,55\%), apabila dibandingkan tahun 2016 sebesar 7.966,57 ton. Khusus ikan tuna hasil produksi mengalami kenaikan $(3,28 \%)$ yaitu pada tahun 2016 sebesar $2.786,21$ ton menjadi 2.877,47 ton pada tahun 2017.

Penelitian sebelumnya yang dilakukan Hartaty dan Ririk (2014) di Pelabuhan Benoa menunjukan bahwa ikan tuna sirip kuning di Samudera Hindia sudah padat tangkap (fully exploited) yaitu nilai eksploitasi sebesar 0,75 (E>0,5).Berdasarkan data dari IOTC (Indian Ocean Tuna Commission) pada tahun 2017, status stok ikan tuna sirip kuning sudah overfishing dengan nilai tangkapan sebesar 39.913 ton yang meliputi WPP 571 (Selat malaka dan Laut Andaman), 572 (Sumatra Barat dan Selat Sunda) dan 573 (Selatan Jawa sampai Nusa Tenggara Timur).

Menurut penelitian Zhu et al., (2010) bahwa ikan tuna sirip kuning di perairan Samudera Atlantik memiliki ukuran antara 83-176 cm dengan modus ukuran $143 \mathrm{cmFL}$, Samudera Hndia ukuran 78-171 cm dengan modus ukuran $125 \mathrm{cmFL}$ dan Samudera Pasifik Timur berukuran 93-170 cm dengan ukuran modus $129 \mathrm{cmFL}$. Menurut Mardlijah \& Rahmat (2012), ikan tuna sirip kuning yang tertangkap di sekitar rumpon di Teluk Tomini berukuran antara 110-190 cmFL dengan modus antara 30-40 cmFL. Hasil penelitian yang dilakukan Nurdin (2012) di PPN Prigi diperoleh ratarata faktor kondisi 1,99. Fauziah \& Aisyah (2011) di Sendang Biru sebesar 1,66.

Tujuan dalam penelitian ini adalah untuk mengetahui sumberdaya ikan tuna sirip kuning di Samudera Hindia berardasarkan tangkapan di Pelabuhan Perikanan Samudera Cilacap dilihat dari aspek biologi yaitu struktur ukuran, panjang berat, faktor kondisi serta ukuran pertama kali tertangkap, sehingga diharapkan dapat menjadi kajian untuk pengelolaan tuna sirip kuning khususnya di Samudera Hindia.

\section{MATERI DAN METODE PENELITIAN}

\section{A. Materi}

Materi yang digunakan pada penelitian tingkat eksploitasi ikan tuna sirip kuning di Samudra Hindia berdasarkan hasil tangkapan ikan tuna sirip kuning yang didaratkan di Pelabuhan Perikanan Samudra Cilacap (PPSC) (Gambar 1).Alat yang digunakan dalam penelitian ini adalah roll meter untuk mengukur panjang ikan sampel dengan panjang total $5 \mathrm{~m}$ dengan ketelitian $1 \mathrm{~mm}$. Timbangan Digital Nagata sebagai alat untuk menimbang berat sampel dengan berat maksimal $300 \mathrm{~kg}$ dengan ketelitian 10 gr.Bahan yang digunakan dalam penelitian ini adalah ikan tuna sirip kuning (T.albacores) yang didaratkan di PPS Cilacap pada bulan Juli-Agustus 2019.

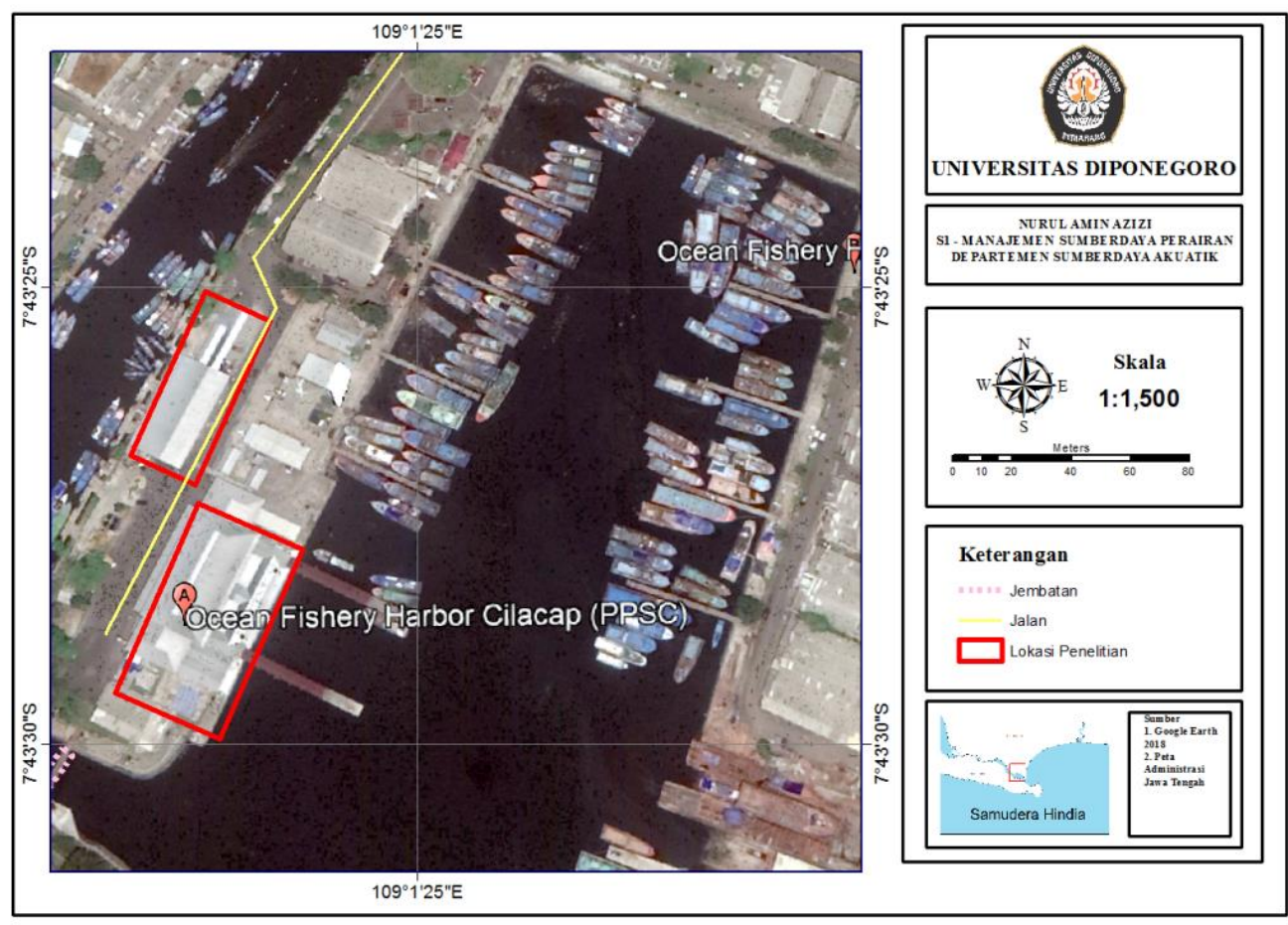

Gambar 1. Lokasi Penelitian

\section{B. Metode Penelitian}

Metode penelitian yang digunakan pada penelitian ini menggunakan metode deskriptif di lokasi penelitian dimana memberikan gambaran mengenai sumberdaya ikan tuna sirip kuning di PPS Cilacap.Menurut Nazir (2005) yang digunakan dalam penelitian deskriptif adalah metode survei.Survei adalah penyelidikan yang diadakan untuk memperoleh fakta-fakta dari gelaja-gejala yang ada dan mencari keterangan-keterangan secara faktual.Survei yang dilakukan pada penelitian ini dengan melakukan pengamatan terhadap jumlah sampel ikan tuna sirip kuning di PPSC meliputi pengamatan panjang dan berat, kemudian dilakukan analisis untuk mengetahui faktor kondisi ikan tuna sirip kuning di perairan Samudra Hindia.

\footnotetext{
${ }^{\odot}$ Copyright by Management of Aquatic Resources (MAQUARES)
} 


\section{a. Metode Pengambilan Sampel}

\section{- Sampel Kapal}

Kapal yang digunakan sebagai sampel merupakan kapal yang menggunakan alat tangkap longline dengan ukuran $>10$ GT. Penentuan sampel kapal dilakukan setiap hari.Jumlah kapal yang mendarat dapat mencapai 6 perhari. Jumlah kapal sampel perhari maksimal 3 karena waktu pembongkaran tiap kapal rata-rata 3 jam perkapal. Jumlah kapal yang digunakan sebagai sampel berjumlah 38 karena tidak setiap hari terdapat kapal tuna yang mendarat.

\section{- Sampel Ikan}

Pengambilan sampel ikan tuna sirip kuning dilakukan setiap hari di PPSC.Sampel ikan tuna yang digunakan berjumlah 276 ekor yang berasal dari ikan tuna yang memiliki ukuran $>0.5$ meter dan berat $>15 \mathrm{~kg}$.

\section{Analisis Data}

\section{- Struktur Ukuran}

Analisis ini digunakan untuk mengetahui frekuensi sebaran ikan kurau yang tertangkap selamaperiode Bulan Juli-Agustus 2019. Rumus yang digunakan yaitu menggunakan persamaan Walpole (1995) dalam Kholis et al. (2018):

$$
\begin{aligned}
& \mathrm{K}=1+3.3 \operatorname{logn} \\
& \mathrm{i}=\text { Nmax-Nmin }
\end{aligned}
$$

Keterangan:

$\mathrm{K}=$ Jumlah kelas $; \mathrm{n}=$ Jumlah data $; \mathrm{i}=$ Selang kelas $; \mathrm{N} \max =$ Nilai terbesar $; \mathrm{N}$ main $=$ Nilai terendah

\section{- Hubungan Panjang Berat} berikut ini:

Analisis hubungan panjang berat yang digunakan oleh Effendi (2002), dapat dinyatakan dalam persamaan

Keterangan:

$$
\mathrm{W}=\mathrm{aL}^{\mathrm{b}}
$$

$\mathrm{W}=$ berat tubuh $($ gram $) ; \mathrm{L}=$ panjang $(\mathrm{mm}) ; \mathrm{a}=$ Intercept $; \mathrm{b}=$ Slope

Bentuk linier dari persamaan tersebut setelah diLog adalah $\log W=\log a+b \operatorname{logL}$.Untuk menguji nilai $b=3$ atau $\mathrm{b} \neq 3$ ( $\mathrm{b}=$ koefisien regresi) dilakukan uji $\mathrm{t}$;

$\mathrm{H} 0: \mathrm{b}=3$, hubungan panjang dan berat adalah isometrik

$\mathrm{H} 1: \mathrm{b} \neq 3$, hubungan panjang dan berat adalah allometrik

Keterangan:

$$
\text { thitung }=\left|\frac{(3-b)}{S b}\right|
$$

$\mathrm{b}=$ Slope $; \mathrm{Sb}=$ Standar deviasi nilai $\mathrm{b}$

\section{- Faktor Kondisi}

Perhitungan faktor kondisi berdasarkan hubungan panjang berat menggunakan rumus $\mathrm{W}=\mathrm{aL}^{\mathrm{b}}$ maka perhitungan faktor kondisi dapat menggunakan faktor kondisi relatif $(\mathrm{Kn})$ yang dirumuskan:

Keterangan:

$$
\mathrm{Kn}=\mathrm{W} / \mathrm{aL}^{\mathrm{b}}
$$

$\mathrm{Kn}=$ faktor kondisi dalam berat total $; \mathrm{W}=$ berat rata-rata ikan $(\mathrm{g}) ; \mathrm{L}=$ panjang rata-rata $\mathrm{ikan}(\mathrm{cm}) ;$

$\mathrm{b}=$ intersept $; \mathrm{a}=$ slope

- Ukuran Pertama Kali Tertangkap (Lc $\left.\mathbf{L}_{\mathbf{5 0} \%}\right)$

Nilai $\mathrm{Lc}_{50 \%}$ diperoleh dengan memplotkan persentase frekuensi kumulatif ikan yang tertangkap dengan ukuran panjang cagaknya, dimana titik potong antara kurva dengan 50\% frekuensi kumulatif adalah panjang saat $50 \%$ ikan tertangkap.

\section{HASIL DAN PEMBAHASAN}

A. Hasil

Gambaran Umum Lokasi Penelitian

Lokasi penelitian dalam pengambilan sampel air dan biota terletak di PPS Cilacap yang merupakan tempat pendaratan ikan yang ditangkap di perairan Samudera Hindia.Berdasarkan hasil yang didapatkan pada bulan JuliAgustus 2019, lokasi penangkapan kapal yang berlabuh dengan hasil tangkapan berupa ikan tuna sirip kuning berada di $8^{\circ}-12^{\circ}$ LS dan $106^{\circ}-110^{\circ}$ BT. Lokasi penangkapan berada di selatan jawa barat dan jawa tengah. Daerah penangkapan ikan berdasarkan data sekunder di PPS Cilacap berada di sekitar pertemuan lempeng HindiaAustralia.Menurut Putra et al. (2016) suhu permukaan laut pada koordinat 7॰-11॰ LS dan $105^{\circ}-109^{\circ} \mathrm{BT}$ antara $27^{\circ}-$ $30{ }^{\circ} \mathrm{C}$. 


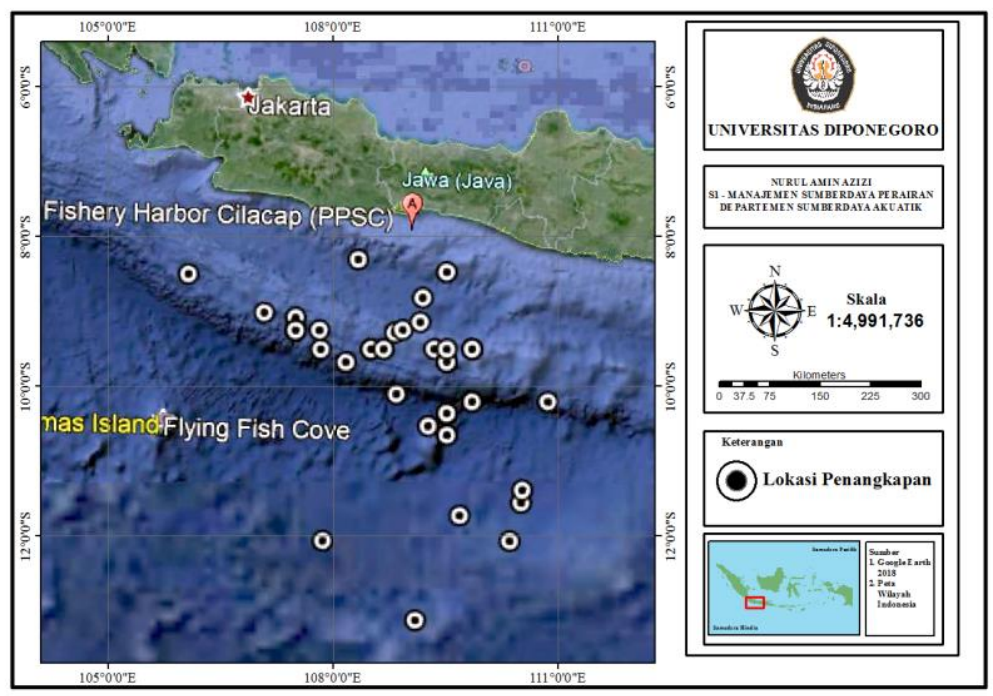

Gambar 2. Lokasi Penangkapan

\section{Struktur Ukuran}

Hasil pengukuran ikan tuna sirip kuning yang didapatkan di PPS Cilacap pada penelitian bulan Juli-Agustus 2019 (Gambar 3), diperoleh data ukuran panjang dan berat yang bervariasi. Ukuran panjang terkecil $88 \mathrm{~cm}$ dan terbesar $174 \mathrm{~cm}$. Ukuran berat terkecil $17 \mathrm{~kg}$ dan terbesar $98 \mathrm{~kg}$. Jumlah ikan tuna sirip kuning yang didapatkan sejumlah 276 ekor.

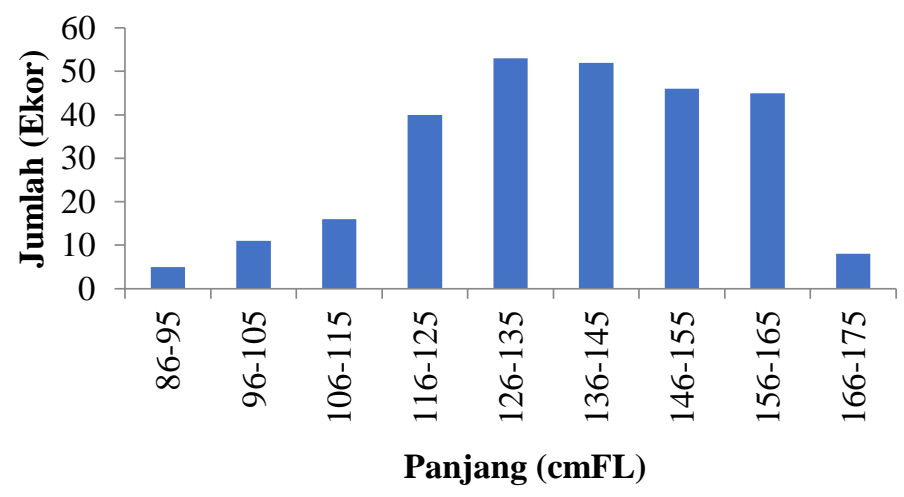

Gambar 3. Distribusi panjang cagak ikan tuna sirip kuning yang didaratkan di PPS Cilacap bulan Juli-Agustus 2019

\section{Hubungan Panjang Berat}

Panjang dan berat ikan tuna sirip kuning yang didapatkan pada bulan Juli - Agustus 2019 di PPS Cilacap (Gambar 4) berkisar antara panjang $88-174 \mathrm{cmFL}$ dan berat 17-98 $\mathrm{kg}$. Hasil perhitungan hubungan panjang berat yang dilakukan memperoleh persamaan $\mathrm{W}=0,000052 \mathrm{FL}^{2,7812}$. Hasil uji t yang dilakukan pada data panjang dan berat dengan selang kepercayaan 95\% diperoleh nilai $t$ hitung $\left(t_{\text {hitung }}=4,24\right)$ lebih besar daripada $t$ table $\left(t_{\text {tabel }}=1,96\right)$, yang artinya pertambahan berat lebih lambat dari pertambahan panjangnya.

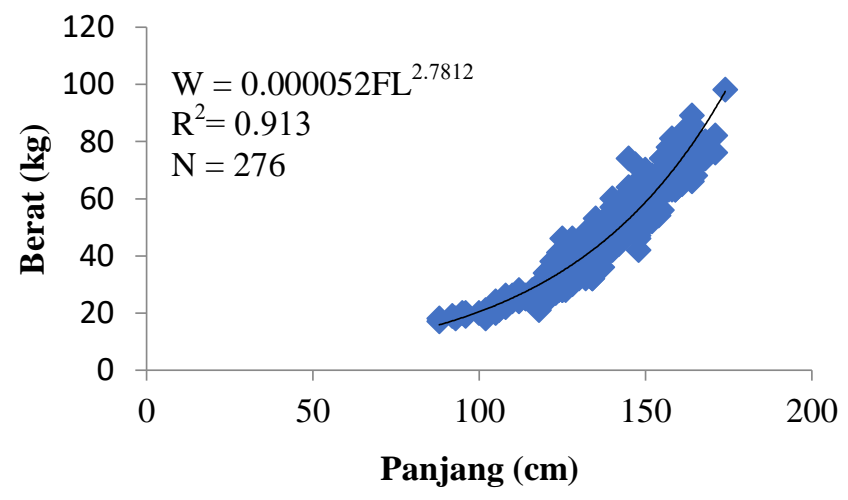

Gambar 4. Hubungan panjang berat ikan tuna sirip kuning yang didaratkan di PPS Cilacap

\footnotetext{
${ }^{\circledR}$ Copyright by Management of Aquatic Resources (MAQUARES)
} 


\section{Faktor Kondisi}

Hasil analisis faktor kondisi yang dilakukan terhadap ikan tuna sirip kuning yang didaratan di PPS Cilacap pada bulan Juli-Agustus didapat nilai 1,03. Faktor kondisi paling rendah berada pada interval 166-175 cmFL yaitu 0,97, sedangkan nilai tertinggi berada pada interval $86-95 \mathrm{cmFL}$, dengan nilai $\mathrm{FK}=1,25$.

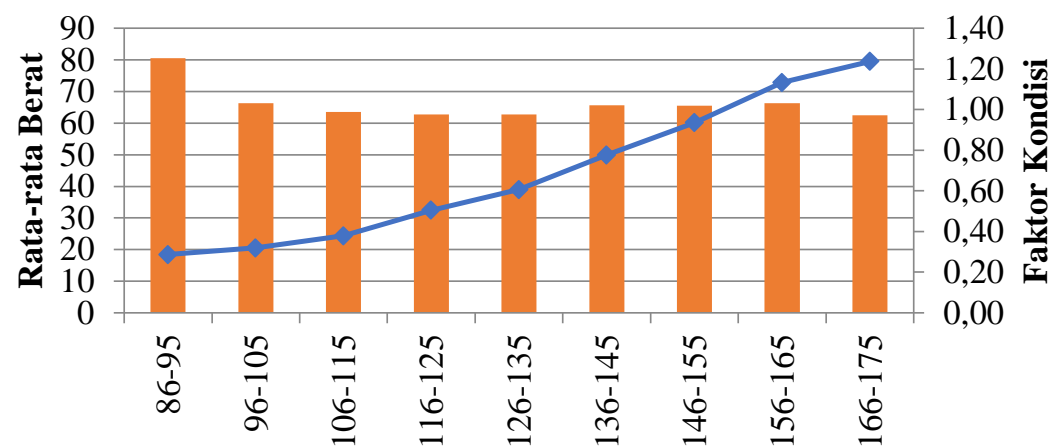

Kisaran Panjang

$\mathrm{K}$ (faktor kondisi) $\quad \longrightarrow$ Rata-rata Berat

Gambar 5. Nilai faktor kondisi ikan tuna sirip kuning yang didaratkan pada PPS Cilacap pada bulan Juli-Agustus 2019

\section{Ukuran Pertama Kali Tertangkap}

Hasil perhitungan ukuran pertama kali tertangkap ikan tuna sirip kuning yang didaratkan di PPS Cilacap (Gambar 6) berdasarkan data ukuran panjang berada pada angka $140 \mathrm{cmFL}$. Ukuran ini berada pada interval 136-145 cmFL. Ukuran pertama kali tertangkap ( $\mathrm{Lc}_{50 \%}$ ) pada penelitian ini menunjukan hasil tangkapan ikan tuna sirip kuning sebagian besar sudah dapat ditangkap karena Lc $<$ Lm. Kenaikan panjang ikan tuna sirip kuning sebanding dengan hasil tangkapan ikan tuna sirip kuning di PPS Cilacap.

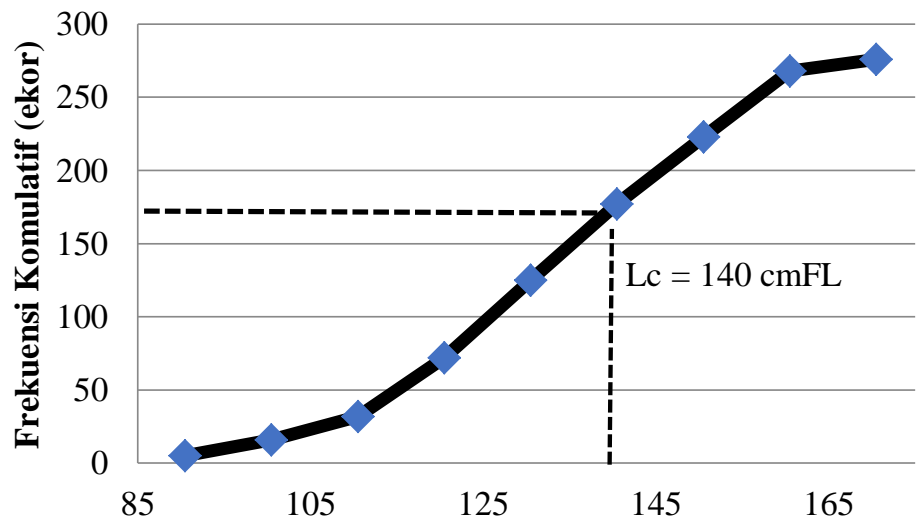

Nilai Tengah Kelas (cmFL)

Gambar 6. Ukuran pertama kali tertangkap ikan tuna sirip kuning yang didaratkan pada PPS Cilacap bulan Juli-Agustus 2019

\section{Rekomendasi Penangkapan Ikan Tuna Sirip Kuning}

Berdasarkan hasil tangkapan dan ukuran matang gonad (Lm) didapatkan bahwa hasil tangkapan yang didapatkan sebagian besar sudah aman ditangkap karena melebihi ukuran matang gonad (Lm). Nilai Lm adalah 100 cmFL (Nugroho et al., 2018) dan ukuran kurang dari $100 \mathrm{cmFL}$ tidak boleh ditangkap karena diduga belum melakukan pemijahan. 


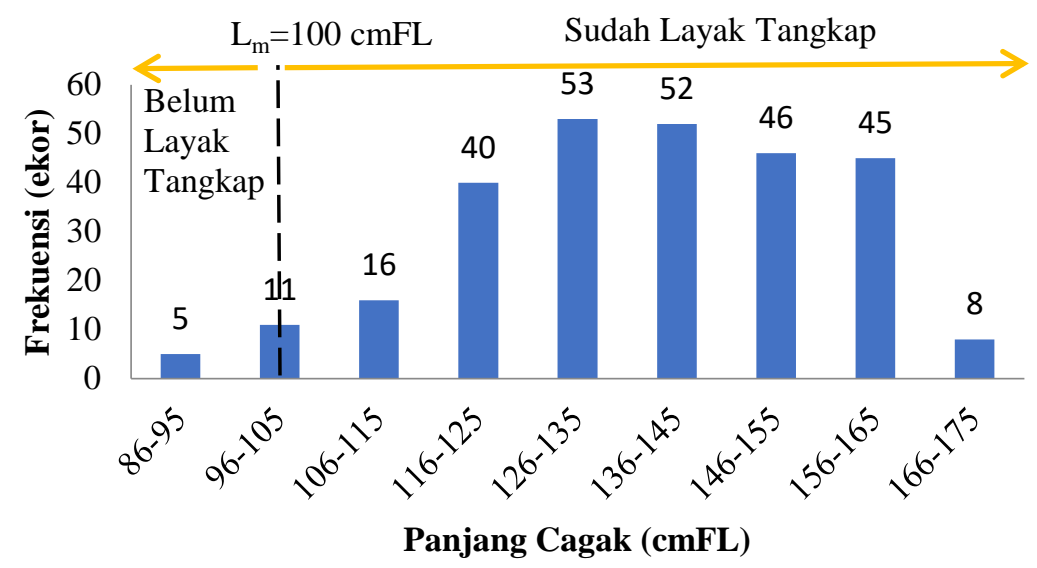

\section{B. Pembahasan}

Gambar 7. Histrogram rekomendasi penangkapan ikan tuna sirip kuning di Samudera Hindia

\section{Struktur Ukuran Ikan Tuna Sirip Kuning}

Hasil tangkapan ikan tuna sirip kuning di Samudera Hindia berdasarkan hasil yang didaratkan di PPS Cilacap pada bulan Juli-Agustus 2019 berasal dari alat tangkap rawai tuna (longline), rawai dasar dan pancing. Hasil tangkapan ikan tuna sirip kuning didominasi oleh alat tangkap longline. Panjang ikan tuna sirip kuning berdasarkan hasil pendaratan ikan di PPS Cilacap berkisar 88-174 cmFL dan berat 17-98 kg. Hasil pengukuran panjang ikan tuna sirip kuning di PPS Cilacap tidak jauh beda dengan hasil penelitian sebelumnya yang dilakukan oleh Nugroho et al.(2018) dengan ukuran tangkapan ikan berkisar antara 76-176 cmFL.

Data hasil distribusi ukuran ikan tuna sirip kuning pada penelitian ini memiliki hasil yang tidak jauh beda dengan penelitian yang sudah dilakukan (Zhu et al., 2010). Perbedaan hasil ukuran yang dilakukan disebabkan oleh beberapa faktor.Faktor yang mempengaruhi perbedaan ukuran jagak dipengaruhi oleh alat tangkap yang digunakan. Semakin besar ukuran mata pancing pada alat tangkap yang digunakan maka semakin besar ukuran yang didapatkan

Distribusi ikan tuna sirip kuning di perairan Samudera Atlantik, Hindia dan Pasifik Timur hampir sama. Menurut penelitian Zhu et al. (2010) bahwa perairan Samudera Atlantik memiliki ukuran antara 83-176 cm dengan modus ukuran $143 \mathrm{cmFL}$, Samudera Hndia ukuran 78-171 cm dengan modus ukuran $125 \mathrm{cmFL}$ dan Samudera Pasifik Timur berukuran 93-170 cm dengan ukuran modus $129 \mathrm{cmFL}$.

\section{Hubungan Panjang Berat dan Faktor Kondisi}

Berdasarkan perhitungan data panjang dan berat didapatkan persamaan eksponensial $\mathrm{W}=0.000052 \mathrm{~L}^{2.7812}$. Persamaan tersebut menunjukan bahwa nilai a (intercept) 0.000052 dan koefisien regresi (slope) 2.7812.Hasil koefisien regresi (b) kurang dari 3 menunjukan bahwa ikan tuna sirip kuning di Samudera Hindia bersifat allometrik negatif.Allometrik negatif mempunyai arti bahwa ikan tuna sirip kuning pertumbuhan panjang lebih cepat daripada beratnya.

Hasil faktor kondisi ikan tuna sirip kuning untuk bulan Juli sampai Agustus 2019 mempunyai hasil berkisar antara 0.97-1.25.Nilai faktor kondisi yang didapatkan dari tuna sirip kuning bervariasi untuk setiap ukuran panjang.Ikan yang memiliki panjang kecil mempunyai nilai faktor kondisi lebih kecil dibandingkan ikan tuna sirip kuning yang besar karena ikan tuna kecil membutuhkan kebutuhan hidup lebih untuk pertumbuhan.Menurut Hossain (2010) mengatakan bahwa faktor kondisi merupakan indikator kesediaan makanan di suatu perairan dan dapat mempengaruhi perkembangan gonad.

\section{Ukuran Ikan Pertama Kali Tertangkap}

Hasil penelitian yang dilakukan pada bulan Juli-Agustus 2019 memperoleh hasil ukuran ikan pertama kali tertangkap (Lc) $140 \mathrm{cmFL}$. Penelitian yang dilakukan Damora \& Baihaqi (2013), panjang ikan tuna sirip kuning pertama kali tertangkap $\left(\mathrm{L}_{\mathrm{c}}\right)$ pancing ulur atau rawai sebesar $133.85 \mathrm{cmFL}$. Ukuran pertama kali matang gonad $\left(\mathrm{L}_{\mathrm{m}}\right)$ berdasarkan penelitian Nugroho et al. (2018) sebesar $100 \mathrm{cmFL}$ dan nilai 1/2 L $\infty$ ikan tuna sirip kuning pada bulan JuliAgustus 2019 sebesar $93 \mathrm{cmFL}$. Hasil perhitungan ukuran pertama kali tertangkap $\left(\mathrm{L}_{\mathrm{c}}\right)$ selama penelitian sebesar 140 $\mathrm{cmFL}$, Nilai $\mathrm{L}_{\mathrm{c}}>\mathrm{L}_{\mathrm{m}}$, menunjukan bahwa ikan tuna sirip kuning pada Samudera Hindia sebagian besar sudah pernah memijah dan dapat dilakukan penangkapan. Rata-rata ikan yang pertama kali tertangkap sudah melewati ukuran matang gonad, maka ikan tuna sirip kuning di Samudera Hindia diduga sudah melakukan reproduksi.

\section{Pengelolaan Tuna Sirip Kuning di Samudera Hindia}

Berdasarkan hasil penelitian ini, ukuran ikan tuna sirip kuning yang ditangkap di PPS Cilacap masih diperbolehkan.Hal ini disebabkan oleh ukuran pertama kali tertangkap (Lc) sudah melebihi ukuran matang gonad (Lm).Ukuran pertama kali tertangkap berada pada $140 \mathrm{~cm}$, sedangkan ukuran matang gonad pada $100 \mathrm{~cm}$. Lc>Lm,

\footnotetext{
${ }^{\odot}$ Copyright by Management of Aquatic Resources (MAQUARES)
} 
menunjukan bahwa sebagian besar ikan tuna yang ditangkap sudah pernah melakukan pemijahan.Kondisi tersebut menunjukan pengelolaan ikan tuna sirip kuning masih stabil.

Kestabilan pengelolaan harus tetap dijaga dan diawasi dari ancaman penangkapan yang semakin padat karena permintaan yang meningkat .Kondisi yang semakin padat tangkap setiap tahun dapat mempengaruhi potensi ikan tuna sirip kuning di Perairan Samudera Hindia menjadi semakin menurun.Akoit \& Nalle (2018) mengatakan bahwa tidak ada populasi ikan yang dapat sanggup bertahan hidup untuk jangka waktu yang panjang jika jumlah yang dipanen lebih besar daripada jumlah ikan yang lahir dan pertumbuhan populasi yang ada.Penambahan jumlah tangkapan dapat mengurangi potensi perikanan hingga nol jika penambahan terus berlangsung setiap musim.

\section{KESIMPULAN}

Berdasarkan penelitian yang telah dilakukan mengenai aspek biologi ikan tuna sirip kuning di Samudera Hindia berdasarkan hasil tangkapan di Pelabuhan Perikanan Samudera Cilacap dapat diperoleh kesimpulan sebagai berikut:

1. Struktur ukuran ikan tuna sirip kuning yang diperoleh pada penelitian bulan Juli-Agustus 2019 dari 267 sampel mempunyai ukuran panjang antara 88-174 cmFL dan berat antara 17-98 kg, dengan modus panjang $125 \mathrm{cmFL}$ dan berat $42 \mathrm{~kg}$.

2. Hubungan panjang dan berat ikan tuna sirip kuning bersifat allometrik negatif yang menunjukan bahwa pertambahan panjang lebih cepat dibandingkan pertambahan berat. Faktor kondisi yang didapatkan sebesar 0.971.25. Faktor kondisi terbesar pada interval $86-95 \mathrm{~cm}$ dan terkecil pada interval $166-175 \mathrm{~cm}$. Hal ini menunjukan bahwa semakin panjang dan berat ikan maka nilai faktor kondisi semakin kecil.

3. Ukuran pertama kali tertangkap (Lc) berada pada $140 \mathrm{cmFL}$ dan Lc $>\mathrm{Lm}$, menunjukan bahwa ikan tuna sirip kuning yang tertangkap di Samudera Hindia sudah pernah memijah dan dapat dilakukan penangkapan.

\section{UCAPAN TERIMA KASIH}

Penulis mengucapkan terimakasih kepada para penguji Ir. Anhar Solichin, M.Si dan Dra. Niniek Widyorini, M.S, atas bimbingan dan arahannya dalam penyusunan jurnal ini serta para pegawai Pelabuhan Perikanan Samudera Cilacap, kedua orang tua dan semua pihak yang tidak dapat disebutkan satu persatu yang telah memberikan dukungan, doa dan terlibat langsung selama penelitian.

\section{DAFTAR PUSTAKA}

Akoit, M.Y. dan M.N Nalle. 2018. Pengelolaan Sumberdaya Perikanan Berkelanjutan di Kabupaten Timor Tengah Utara Berbasis Pendekatan Bioekonomi. Jurnal Agribisnis Indonesia. 6(2): 85-108.

Adhitya, E. K., A. Rosyid, dan H. Boesono. 2012. Rancangan Sistem Informasi pada Usaha Pengkapan Ikan Komoditas Unggulan ( Study Kasus Ikan Tuna (Thunus Sp) di Pelabuhan Perikanan Samudra Cilacap. Jurnal Manajemen Pemanfaatan Sumber Daya Perikanan dan Teknologi. 1(1): 108-117

Damora, A. dan Baihaqi.2013. Struktur Ukuran Ikan dan Parameter Populasi Madidihang (Thunnus albacares) di Perairan Laut Banda.BAWAL. 5 (1): 59-65

Effendie. 2002. Biologi Perikanan. Yayasan Pustaka Nusantara, Yogyakarta

Faizah R dan Aisyah. 2011. Komposisi Jenis dan Distribusi Ukuran Ikan Pelagis Besar Hasil Tangkapan Pancing Ulur di Sendang Biru, Jawa Timur. Bawal. 3(6): 377-385

Hartaty, H., dan Ririk K.S. 2014. Pendugaan Parameter Populasi dan Tingkat Pemanfaatan Ikan Madidihang (Thunnus albacares) yang Didaratkan di Benoa, Bali.Jurnal Penelitian Perikanan Indonesia. 20(2): 97-103

Hossain Y. 2010. Length-Weight, Length-Length Relationship and Condition Factors of Three Schibid Catfish from the Padma River, Northwestern Bangladesh. Asian Fisheries Science. 23:329-339

Kholis, M.N., R.I.Wahju, Mustaruddin, Jaliadi. 2018. Struktur Ukuran dan Hubungan Panjang Berat Ikan Kurau di Pulau Bengkalis. Albacore. 2(2): 197-208

Mardlijah, S. dan E. Rahmat. 2012. Penangkapan juvenile ikan madidihang (Thunnus albacares Bonnatere,1788) di perairan Teluk Tomini. BAWAL. 4(3) : 169-176

Nazir. 2005. Metode Penelitian. Ghalia Indonesia, Jakarta

Nugroho, S. C., I. Jatmiko, A. Wujdi. 2018. Pola pertumbuhan dan faktor kondisi madidihang, Thunnus albacares (Bonnaterre, 1788) di Samudra Hindia Bagian Timur. Jurnal Iktiologi Indonesia. Vol 18(1): 13-21

Nurdin, E, A.A Taurusman, R. Yusfiandayani. 2012. Struktur Ukuran, Hubungan Panjang Bobot dan Faktor Kondisi Ikan Tuna di Perairan Prigi, Jawa Timur. Bawal. 4(2): 67-73

Putra, F. A., Z. Hasan, N. P. Purba. 2016. Kondisi Arus dan Suhu Permukaan Laut pada Musim Barat dan Kaitannya dengan Ikan Tuna Sirip Kuning (Thunnus Albacares) Di Perairan Selatan Jawa Barat. Jurnal Perikanan Kelautan. 7(1): 156-163

Zhu, G., L. Xu, Y. Zhou, L. Song and X. Dai. (2010). Length-Weight Relationships For Bigeye Tuna (Thunnus Obesus), Yellowfin Tuna (Thunnus Albacares) And Albacore (Thunnus Alalunga) (Perciformes: Scombrinae) In The Atlantic, Indian And Eastern Pacific Oceans Collective Volume of Scientific Papers. ICCAT. 65(2): 717-724 